\title{
GURU YANG BERMORAL DALAM KONTEKS SOSIAL, BUDAYA, EKONOMI, HUKUM DAN AGAMA (Kajian Terhadap UU No 14 Tahun 2005 Tentang Guru Dan Dosen)
}

Syarnubi

Dosen FITK UIN Raden Fatah Palembang

Email:syarnubi@radenfatah.ac.id

\begin{abstract}
ABSTRAK
Penelitian ini mengkaji pentingnya kompetensi kepribadian guru bahkan kompetensi ini melandasi atau menjadi landasan utama bagi kompetensi-kompetensi lainya. Dalam hal ini, guru tidak hanya dituntut untuk mampu memaknai pembelajaran, tetapi dan yang paling penting adalah bagaimana dia menjadikan pembelajaran sebagai ajang pembentukan kompetensi dan perbaikan kualitas pribadi peserta didik.

Penelitian ini merupakan studi pustaka (library research) yaitu penelitian yang bersumber dari bahan-bahan kepustakaan dengan menggunakan pendekatan kualitatif. Oleh karena itu, yang dilakukan adalah eksplorasi terhadap sejumlah data baik itu data primer maupun data sekunder dengan langkah konkret sebagai berikut: membaca serta menelaah secara mendalam data primer seperti buku, hasil penelitian skripsi, tesis maupun disertasi yang terkait dengan kompetensi kepribadian. Karena itu, sosok guru yang bermoral merupakan suatu keharusan.

Ujian berat bagi guru dalam hal kepribadian ini adalah rangsangan yang sering memancing emosinya. Kestabilan emosi sangat diperlukan, namun tidak semua orang mampu menahan emosi terhadap rangsangan yang menyinggung perasaan, dan memang diakui bahwa tiap orang memiliki tempramen yang berbeda dengan orang lain. Untuk keperluan tersebut, upaya dalam bentuk latihan mental akan sangat berguna. Guru yang mudah marah akan membuat peserta didik takut, dan ketakutan mengakibatkan kurangnya minat untuk mengikuti pemebalajaran serta rendahnya konsentrasi, karena ketakutan menimbulkan kekuatiran untuk dimarahi dan hal ini membelokkan konsentrasi peserta didik.
\end{abstract}

Keywords: Guru dan Dosen, Moral, Konteks Sosial 


\section{PENDAHULUAN}

Penyelenggaraan pendidikan melalui jalur sekolah tidak dapat dilepaskan dari unsur guru sebagai tenaga pendidik. Demikian penting unsur ini sehingga selalu dikaitkan dengan kualitas pendidikan, yang dicerminkan melalui kualitas lulusan suatu sekolah. Kualitas pendidikan yang rendah, cenderung dialamatkan pada guru sebagai penyebab utamanya. Kelemahan dan kekurangan pada unsur lain seperti sarana prasarana, kesejahteraan, kurikulum, sistem penilaian dan lain-lain sering tidak terlihat dan diabaikan.

Pribadi guru memiliki andil yang sangat besar terhadap keberhasilan pendidikan, khususnya dalam kegiatan pembelajaran. Pribadi guru juga sangat berperan dalam membentuk pribadi peserta didik. Ini dapat dimaklumi karena manusia merupakan mahkluk yang suka mencontoh, termasuk mencontoh pribadi gurunya dalam membentuk pribadinya. Semua itu menunjukkan bahwa kompetensi personal atau kepribadian guru sangat dibutuhkan oleh peserta didik dalam proses pembentukan pribadinya. Oleh karena itu wajar, ketika orang tua mendaftarkan anaknya ke suatu sekolah akan mencari tahu siapa guru-guru yang akan membimbing anaknya.

Guru yang baik akan dihormati dan disegani oleh siswa. Jadi guru harus bertekad mendidik dirinya sendiri lebih dahulu sebelum mendidik orang lain. Pendidikan melalui keteladanan adalah pendidikan yang efektif. Guru yang disenangi, otomatis mata pelajaran yang ia ajarkan akan disenangi oleh siswa, dan siswa akan bergairah dan termotivasi sendiri mendalami mata pelajaran tersebut. Sebaliknya guru yang dibenci oleh siswa, akan tidak senang dengan mata pelajaran yang dipegang oleh guru tersebut, dan membentuk sikap antipatik terhadap mata pelajaran yang dipelajari tersebut.

Kompetensi kepribadian sangat besar pengaruhnya terhadap pertumbuhan dan perkembangan pribadi para peserta didik. Kompetensi kepribadian ini memiliki peran dan fungsi yang sangat penting dalam membentuk kepribadian anak, guna menyiapkan dan mengembangkan sumber daya manusia (SDM), serta mensejahterakan masyarakat, kemajuan negara, dan bangsa pada umumnya. Oleh karenanya, setiap guru dituntut untuk memiliki kompetensi kepribadian yang memadai, bahkan kompetensi ini melandasi atau menjadi landasan utama bagi kompetensi-kompetensi lainya.

\section{METODE PENELITIAN}

\section{Jenis Penelitian}

Penelitian ini termasuk library research, karena itu yang dilakukan adalah eksplorasi terhadap sejumlah data baik data primer, maupun data sekunder dengan langkah konkret sebagai berikut: membaca serta menelaah secara mendalam data primer seperti buku yang merupakan hasil penelitian, tesis maupun disertasi mengenai kompetensi kepribadian guru, sementara itu 
untuk data sekunder peneliti akan membaca dan menelaah buku, tulisan, artikel dan jurnal yang relevan dengan penelitian peneliti.

\section{Metode pengumpulan Data}

Metode pengumpulan data dengan mengumpulkan buku-buku, artikel, jurnal, opini yang di dalamnya mengungkap dan mengkaji kompetensi kepribadian guru, setelah seluruh data terkumpul kemudian dilakukan sebuah pemilahan antara buku, artikel, jurnal yang membahas kompetensi kepribadian guru. Selanjutnya dilakukan analisis secara deduktif dan induktif.

\section{Metode Analisis Data}

Analisis data merupakan suatu cara untuk mengolah data yang diperoleh selama penelitian dilakukan sehingga dapat ditarik kesimpulan. Setelah data kompetensi kepribadian guru telah terkumpul, kemudian dianalisis dengan metode deskriptif-analytic. Deskriptif adalah metode yang menggunakan pencarian fakta yang diinterpretasi dengan tepat, sedangkan analisis adalah menguraikan sesuatu dengan cermat serta terarah. Data yang telah dianalisis kemudian dipaparkan dengan metode deduktif yang berangkat dari teori umum untuk menuju pada kesimpulan yang merupakan jawaban dari rumusan masalah penelitian ini.

\section{HASIL PENELITIAN}

\section{A. UU No. 14 Tahun 2005 tentang Guru dan Dosen}

Salah satu tujuan pokok negara sebagai mana tertuang dalam pembukaan UUD 1945 alenia keempat ialah mencerdaskan kehidupan bangsa. Ini artinya, sejak awal berdirirnya negara, kebodohan dan tingkat ilmu pengetahuan masyarakat yang rendah merupakan persoalan riil yang perlu ditangani melalui sistem pendidikan nasional yang menyeluruh dan terpadu. Perlu pembenahan, pembaharuan, peningkatan, dan intensifikasi yang terusmenerus salah satunya dengan disahkannya undang-undang guru dan dosen.

Guru merupakan komponen paling menentukan dalam sistem pendidikan secara keseluruhan, yang harus mendapat perhatian sentral, pertama dan utama, figur yang satu ini akan senantiasa menjadi sorotan strategis ketika berbicara masalah pendidikan, karena guru selalu terkait dengan komponen manapun dalam sistem pendidikan.

Guru juga sangat menentukan keberhasilan peserta didik, terutama dalam kaitannya proses pembelajaran. Oleh karena itu, upaya perbaikan apapun yang dilakukan untuk meningkatkan kualitas pendidikan tidak akan memberikan sumbangan yang signifikan tanpa didukung oleh guru yang profesional dan berkualitas. Dengan kata lain, perbaikan kualitas pendidikan harus berpangkal dari guru dan berujung pada guru pula.

Menurut UU No. 14 Tahun 2005 tentang Guru dan Dosen pada Bab IV Pasal 8 dijelaskan bahwa guru wajib memiliki kualifikasi akademik, kompetensi, sertifikat pendidik, sehat jasmani dan rohani, serta memiliki 
kemampuan untuk mewujudkan tujuan pendidikan nasional. Selanjutnya dijelaskan pada pasal 10 bahwa kompetensi guru sebagaimana yang dimaksud dalam pasal 8 meliputi kompetensi pedagogik, kompetensi kepribadian, kompetensi sosial, dan kompetensi profesional yang diperoleh melalui pendidikan profesi. $^{1}$

Penjelasan Undang-undang No. 14 Tahun 2005 tentang Guru dan Dosen yang dimaksud dengan kompetensi kepribadian adalah "kemampuan kepribadian yang mantap, berakhlak mulia, arif, dan berwibawa serta menjadi teladan peserta didik". ${ }^{2}$

\section{Kepribadian yang mantap dan stabil}

Agar dapat melaksanakan tugasnya dengan baik, profesional dan dapat dipertanggungjawabkan, guru harus memiliki kepribadian yang mantap, stabil dewasa. Hal ini penting, karena banyak masalah pendidikan yang disebabkan oleh faktor kepribadian guru yang kurang mantap, kurang stabil, dan kurang dewasa. Kondisi kepribadian yang demikian sering membuat guru melakukan tindakan-tindakan yang tidak profesional, tidak terpuji, bahkan tindakan-tindakan tidak senonoh yang merusak citra dan martabat guru. Berbagai kasus yang disebabkan oleh kepribadian guru yang kurang mantaf, kurang stabil, dan kurang dewasa, sering kita dengar di berita-berita elektronik atau kita baca diberbagai majalah dan surat kabar. Misalnya: adanya oknum guru yang menghamili peserta didik. Adanya oknum guru yang terlibat pencurian, penipuan, dan kasus-kasus lain yang tidak pantas dilakukan oleh guru. Dalam kaitan inilah pentingnya guru memiliki kepribadian yang mantap, stabil dan dewasa.

Perasaan dan emosi guru yang mempunyai kepribadian terpadu tampak stabil, optimis dan menyenangkan. Dia dapat memikat hati peserta didiknya, karena setiap anak merasa diterima dan disayangi oleh guru, betapapun sikapnya. Dalam hal perbedaan pendapat dan masing-masing merasa paling benar ini dapat menimbulkan ketegangan atau membuat guru emosi. $^{3}$

Guru yang goncang atau tidak stabil emosinya, misalnya mudah cemas, penakut, pemarah, penyedih dan pemurung. Peserta didik akan terombang-ambing dibawa oleh arus emosi guru yang goncang tersebut karena peserta didiknya yang masih dalam pertumbuhan jiwa itu juga dalam keadaan tidak stabil, karena masih dalam pertumbuhan dan perubahan. Biasanya guru yang tidak stabil emosinya tersebut, tidak menyenangkan

\footnotetext{
${ }^{1}$ Undang-undang Republik Indonesia no 14 tahun 2005 tentang Guru dan Dosen, (Yogyakarta: Pustaka Pelajar. 2009), hal. 11

${ }^{2}$ Ibid., hal. 67

${ }^{3}$ Syarnubi, S. (2017). Manajemen Konflik Dalam Pendidikan Islam dan Problematikanya: Studi Kasus di Fakultas Dakwah UIN-SUKA Yogyakarta. Tadrib: Jurnal Pendidikan Agama Islam, 2(1), 151-178.
} 
bagi peserta didik, karena mereka seringkali merasa tidak dimengerti oleh guru. Kegoncangan peserta didik itu akan menyebabkan kurangnya kemampuannya untuk menerima dan memahami pelajaran, sebab konsentrasi pikirannya diganggu oleh perasaaan yang digoncang karena melihat atau menghadapi guru yang emosinya tidak stabil.

Guru yang pemarah atau keras, akan menyebabkan peserta didik takut. Ketakutan itu dapat tumbuh atau berkembang menjadi benci. Karena takut itu menimbulkan derita atau ketegangan dalam hati peserta didik, jika sering menderita oleh seorang guru, maka guru tersebut akan dijauhinya agar dapat menghindari derita yang mungkin terjadi. Akan tetapi sebagai peserta didik yang harus patuh dan tunduk kepada peraturan sekolah, ia terpaksa tetap berada dalam kelas, ketika guru tersebut ada, maka lambat laun guru itu akan berhubungan secara negatif dalam hati peserta didiknya, artinya ia akan membencinya. Apabila peserta didik benci terhadap guru, maka ia tidak akan berhasil mendapat bimbingan dan pendidikan dari guru tersebut, selanjutnya ia akan menjadi bodoh walaupun kecerdasannya tinggi.

Demikian pula dengan berbagai emosi lainnya yang tidak stabil, akan membawa kepada kegoncangan emosi pula pada peserta didik, bahkan mungkin akan melahirkan kekerasan dalam pendidikan selain itu akan membawa kepada kegoncangan kejiwaan. ${ }^{4}$

Ujian berat bagi guru dalam hal kepribadian ini adalah rangsangan yang sering memancing emosinya. Kestabilan emosi sangat diperlukan, namun tidak semua orang mampu menahan emosi terhadap rangsangan yang menyinggung perasaan, dan memang diakui bahwa tiap orang memiliki tempramen yang berbeda dengan orang lain. Untuk keperluan tersebut, upaya dalam bentuk latihan mental akan sangat berguna. Guru yang mudah marah akan membuat peserta didik takut, dan ketakutan mengakibatkan kurangnya minat untuk mengikuti pembelajaran serta rendahnya konsentrasi, karena ketakutan menimbulkan kekuatiran untuk dimarahi dan hal ini membelokkan konsentrasi peserta didik. ${ }^{5}$

\section{Berakhlak Mulia}

Guru adalah panutan oleh karena itu guru harus berakhlak mulia, karena ia adalah penasehat bagi peserta didik, bahkan orang tua bagi peserta didik yang akan dicontoh dan diikuti oleh peserta didik. Cara guru berpakaian, berbicara, berjalan dan bergaul juga merupakan penampilan kepribadian lain, yang mempunyai pengaruh terhadap peserta didiknya. Termasuk pula dalam masalah kepribadian guru tersebut, sikap dan pandangan guru terhadap fungsinya bagi peserta didiknya. Apakah ia

${ }^{4}$ Zakiah Daradjat, Kepribadian Guru, (Jakarta: PT Bulan Bintang, 2005) hal. 11

${ }^{5}$ E. Mulyasa, Standar Kompetensi dan Sertifikasi Guru, (Bandung: PT Remaja Rosdakarya, 2007), hal. 121. 
sebagai pemimpin, yang menyuruh, memerintah, dan mengendalikan? Sedangkan peserta didik adalah yang dipimpin harus patuh menurut dan penerima. Taukah ia sebagai pembimbing yang mengerti dan menyiapkan susana bagi peserta didik, ia hidup dan ikut aktif dalam kegiatannya.

Pertama, yang menempatkan dirinya sebagai pemimpin yang memerintah dan menyuruh akan bersikap besar, sungguh-sungguh dan menampakkan diri dalam bentuk yang ideal. Hubungan antara guru dan peserta didik dalam hal ini, adalah seperti atasan dan bawahan. Jika peserta didik patuh, maka kepatuhan itu tidak akan berlangsung lama, dan tidak menguntungkan dalam pendidikan, karena peserta didik dalam mematuhi itu mengalami ketegangan atau merasa terpaksa. Peserta didik tidak akan merasa aman terhadap guru yang seperti itu, mungkin mereka akan menjauh atau putus asa, karena tidak mampu mengikuti guru tersebut.

Kedua, lain halnya dengan pertama, yang merasa bahwa dirinya adalah pembimbing bagi peserta didiknya, ia menyiapkan susana yang mebantu mereka, ia ikut aktif dalam proses pembelajaran, ia menampakkan diri sebagaimana adanya, tidak berpura-pura hebat atau seram, hubungan dengan peserta didik sederhana dan wajar, atau dapat dikatakan seperti hubungan kakak dan adik. Biasanya guru yang seperti ini menarik dan menyenangkan bagi peserta didik, ia akan dihormati, disayangi dan dipatuhi dengan gembira oleh peserta didik. Pribadinya akan dicontoh dan pelajarannya akan diperhatikan serta diminati oleh peserta didik.

Kompetensi kepribadian guru yang dilandasi akhlak mulia tentu saja tidak tumbuh dengan sendirirnya begitu saja, tetapi memerlukan ijtihad yang mujahadah, yakni usaha sungguh-sungguh, kerja keras, tanpa menganal lelah, dengan giat ibadah tentunya. Dalam hal ini barangkali, setiap guru harus merapatkan kembali barisannya, meluruskan niat, bahwa menjadi guru bukan semata-mata untuk kepentingan duniawi, memperbaiki ikhtiar terutama berkaitan dengan kompetensi kepribadiannya, dengan tetap bertawakal kepada Allah. Melalui guru yang demikianlah, kita berharap pendidikan menjadi ajang pembentukan karakter bangsa.

\section{Disiplin, Arif dan Berwibawa}

Banyak peserta didik yang berlaku kurang senonoh di sekolah maupun di masyarakat yang menimbulkan kekhawatrian di kalangan orang tua, terlibat video porno di handphone, geng motor, narkoba dan lainnya, berangkat dari pribadi yang kurang disiplin. Oleh karena itu, peserta didik harus belajar disiplin, dan gurulah yang harus memulainya, sebagai guru dia harus memiliki kepribadian yang disiplin, arif dan berwibawa.

Untuk mendisiplinkan peserta didik, guru dituntut untuk melakukan hal-hal sebagai berikut: ${ }^{6}$

${ }^{6}$ E. Mulyasa , Standar Kompetensi dan Sertifikasi Guru, (Bandung: PT Remaja Rosdakarya, 2008), hal. 125 
a. Mempelajari pengalaman peserta didik di sekolah melalui kartu catatan kumulatif;

b. Mempelajari nama-nama peserta didik secara langsung, misalnya melalui daftar hadir kelas.

c. Mempertimbangkan lingkungan sekolah dan lingkungan peserta didik.

d. Memberi tugas yang jelas, dapat dipahami, sederhana dan tidak bertele-tele.

e. Menyiapkan kegiatan sehari-hari agar apa yang dilakukan dalam pembelajaran sesuai dengan yang direncanakan, tidak terjadi banyak penyimpangan.

f. Berdiri di dekat pintu pada waktu mulai pergantian pelajaran agar peserta didik tetap berada dalam posisinya sampai pelajaran berikutnya dilaksanakan.

g. Bergairah dan semangat dalam melakukan pembelajaran, agar dijadikan teladan oleh peserta didik.

h. Berbuat sesuatu yang bervariasi, jangan monoton, sehingga membantu disiplin dan gairah belajar peserta didik.

i. Menyesuaikan ilustrasi dan argumentasi dengan kemampuan peserta didik, jangan memaksakan peserta didik sesuai dengan pemahaman guru, atau mengukur peserta didik dari kemampuan gurunya.

j. Membuat peraturan yang jelas dan tegas agar bisa dilaksanakan dengan sebaik-baiknya oleh peserta didik.

Sedangkan kepribadian yang arif adalah bijak dalam menggunakan pikiran ditunjukkan dengan sikap terbuka dalam berfikir dan bertindak, segala sesuatu yang dilakukan atas dasar manfaat terhadap peserta didik. Sekolah maupun masyarakat.

Dengan kepribadian yang arif, seorang guru harus terbuka dan berjiwa besar mau menerima saran atau kritikan yang membangun dari peserta didik. Seorang guru yang arif harus peka dengan menyadari bahwa semua yang berada disekitar peserta didik dapat menjadi sumber belajar, sedang dirinya hanya sebatas fasilitator.

Sikap guru dalam menghadapi segala persoalan, baik menghadapi peserta didik, teman-temannya sesama guru, kepala sekolah dan sekolah itu sendiri akan dilihat, diamati dan dinilai pula oleh peserta didik. Sikap pilih kasih dalam memperlakukan peserta didik, adalah yang paling cepat dirasakan oleh peserta didik, karena semua peserta didik mengharapkan perhatian dan kasih sayang gurunya. Kelakuan peserta didik tidak boleh dijadikan alasan untuk membedakan perhatian, karena anak yang nakal misalnya, sering dimarahi dan dibenci oleh guru, karena ia sering mengganggu suasana sekolah. Akan tetapi guru yang bijaksana tidak akan benci kepada peserta didik yang nakal, dia akan lebih memperhatikannya 
dan berusaha mengetahui latar belakang peserta didik tersebut. Selanjutnya berusaha memperbaikinya secara individual mungkin dengan mengajaknya bicara dikantor atau di luar jam sekolah bahkan menghubungi orang tuanya dan sebagainya. Boleh jadi kenakalan itu terjadi karena si anak merasa tidak disayangi oleh orang tuanya, atau karena suasana keluarganya goncang dan menegangkan, sehingga ia bingung dan tertekan perasaan maka gurulah orang terdekat tempat memantulkan perasaannya yang goncang tersebut.

Selain itu kepribadian yang berwibawa ditunjukkan dengan pergaulan guru di sekolah tidak menutup diri, akan tetapi guru merupakan bagian dari siswa. oleh karena itulah untuk mengetahui keadaan peserta didik guru harus terjun langsung menjadi sahabat bagi peserta didik.

\section{Menjadi Tealadan Bagi Peserta Didik}

Guru merupakan teladan bagi peserta didik dan semua orang yang menganggap dia sebagai guru. Sebagai teladan, tentu saja pribadi dan apa yang dilakukan guru akan mendapat sorotan peserta didik serta orang disekitar lingkungannya yang menganggap atau mengakuinya sebagai guru. $^{7}$

Tingkah laku atau moral guru pada umumnya, merupakan penampilan lain dari kepribadiannya. Bagi peserta didik yang masih kecil, guru adalah contoh teladan yang sangat penting dalam pertumbuhannya, guru adalah orang pertama sesudah orang tua, yang mempengaruhi pembinaan kepribadian peserta didik. Kalaulah tingkah laku atau akhlak guru tidak baik, pada umumnya akhlak peserta didik akan rusak olehnya, karena anak mudah terpengaruh oleh orang yang dikaguminya. Atau dapat juga menyebabkan peserta didik gelisah, cemas atau terganggu jiwa karena ia menemukan contoh yang berbeda atau berlawanan dengan contoh yang selama ini didapatnya di rumah dari oramg tua.

Secara teoritis, menjadi teladan merupakan bagian integral dari seorang guru, sehingga menjadi guru berarti menerima tanggung jawab untuk menjadi teladan. Memang setiap profesi mempunyai tuntutantuntutan khusus, dan karenanya bila menolak berarti menolak profesi itu.

\section{B. Guru Yang Bermoral Dalam Konteks Sosial, Budaya, Ekonomi, Hukum dan Agama}

\section{Konteks Sosial}

UU NO. 14 Tahun 2005 Tentang Guru dan Dosen terkait dengan kompetensi kepribadian ditinjau dalam konteks sosial, mampu memberdayakan Pendidikan Masyarakat atau disebut dengan learning society yakni memberdayakan peran masyarakat dan keluarga dalam bidang pendidikan. Selama ini peran lembaga pendidikan formal, dalam arti

${ }^{7}$ Bagus Herdananto, Menjadi Guru Bermoral Profesional, (Yogyakarta: Kreasi Wacana, 2009), hal. 21 
sekolah, yang baru mendapat perhatian. Sementara pendidikan non formal dan informal di Indonesia belum mendapatkan perhatian, andai mendapatkan perhatian hanya dalam porsi yang sedikit.

Pemahaman akan dunia pendidikan yang terfokus pada pendidikan formal saja tidaklah tepat, sebab konsep pendidikan (mendidik) yang ada diartikan secara luas. Kegiatan pendidikan tidak hanya terjadi di lingkungan sekolah, akan tetapi juga di lingkungan keluarga dan lingkungan masyarakat. Pada gilirannya nanti tidak hanya pendidikan formal dalam artian sempit, sekolah, yang mendapatkan perhatian, akan tetapi juga pendidikan di lingkungan keluarga dan di lingkungan masyarakat (diluar sekolah).

Pemahaman yang sekarang berkembang adalah menekankan pendidikan formal pada lingkungan sekolah, sehingga sekolah mendapat perhatian yang cukup besar. Sebagai kosekuensinya, apabila terjadi suatu ketidakselarasan atau penyimpangan pendidikan yang berlangsung dengan tujuan yang ditetapkan, maka sekolah akan mendapatkan sorortan yang paling tajam. Sementara pendidikan diluar sekolah dan pendidikan keluarga kurang mendapatkan perhatian, atau bahkan cenderung terabaikan. Inilah yang kemudian membuat situasi pendidikan terlihat pincang, sebab setiap pertumbuhan setiap manusia atau setiap masyarakat tidak hanya ditentukan oleh pengalaman pendidikan formal. Pengaruh-pengaruh yang datang dari pengalaman-pengalaman pendidikan non formal dan informal sungguh tidak kalah penting. Dari sini dapat dilihat arti penting pendidikan dalam lingkungan di luar sekolah dan pendidikan di luar keluarga. Untuk itu dibutuhkan kondisi yang mendukung terciptanya suatu masyarakat dan keluarga yang terdidik. Yang dimaksud terdidik disini tidak hanya kemampuan transfer ilmu, akan tetapi juga transfer internalisasi nilai-nilai, sehingga akan membentuk watak bangsa yang tidak hanya cerdas, tetapi juga bermoral.

Selain itu mampu menumbuhkan sifat toleransi, tenggang rasa dan mencintai sesama manusia. Menghargai peserta didik yang berasal dari beranekaragam suku, ras, agama dan lain-lain.

Darai uaraian di atas dapat disimpulkan bahwa, kompetensi kepribadian ditinjau dalam konteks sosial mempunyai nilai filosofis upaya untuk memberdayakan pendidikan masyarakat, disisi lain kebijakan tentang undang-undang guru dan dosen terkait kompetensi kepribadian guru sebagai agen pembelajaran hanya terfokus pada pendidikan formal saja kurang memperhatikan pendidikan non formal dan informal, karena keberhasilan pendidikan yang dilakukan oleh guru tidak hanya di ukur dari ranah kognitif (kecerdasan) saja tapi harus memperhatikan ranah afektif dan psikomotorik. Selanjutnya sikap toleransi harus tertanam pada ssosok guru yang bermoral 
sehingga dalam proses pembelajaran tidak membeda-bedakan satu dengan yang lainnya berdasarkan ras, suku, agama, dan lain-lain.

\section{Konteks Budaya}

Selanjutnya kompetensi kepribadian ditinjau dalam konteks budaya, dapat menciptakan proses pembelajaran atraktif. Pembelajaran aktraktif adalah suatu proses pembelajaran yang mempesona, menarik, mengasyikkan, menyenangkan, tidak membosankan, variatif, kreatif dan indah. Fenomena yang terjadi saat ini sebagian guru-guru enggan untuk mengadakan pembaharuan dalam strategi dan metode pembelajaran. Sehingga proses pembelajaran menjadi pasif, monoton, yang mengakibatkan peserta didik menjadi bosan cenderung tidak memperhatikan apa yang disampaikan oleh guru, oleh sebab itu proses pembalajaran yang monoton, pasif, akan mengakibatkan tindak kekerasan yang dilakukan oleh guru terhadap peserta didik karena merasa tidak diperhatikan oleh peserta didik.

Kekerasan-kekerasan yang dilakukan oleh guru kepada peserta didik seperti dilempar penghapus dan penggaris, dijemur di lapangan, dan dipukul. Di samping itu peserta didik juga mengalami kekerasan psikis dalam bentuk bentakan dan kata makian, seperti bodoh, goblok, kurus, ceking dan sebagainya. Hal-hal seperti inilah yang harus dihindari oleh guru.

Guru sebagai bagian dari kerangka sistem pendidikan diharapkan selalu mengembangkan keterampilan mengajar yang sesuai dengan kemajuan zaman dan lingkungan lokal dimana proses pendidikan itu dilaksanakan. Jika guru bersikap statis (merasa cukup dengan apa yang sudah ada) maka proses pendidikan itu pun akan statis bahkan mundur. Sikap ini pada gilirannya berdampak pada kualitas lulusan. Posisi strategis guru dalam memberdayakan peserta didik dan proses pembelajaran menuntut guru selalu melakukan pengembangan dan pembaruan (berinovasi).

Seorang guru hendaknya mengetahui bagaiman cara peserta didik belajar dengan baik dan berhasil. Berikut ini adalah unsur-unsur pokok yang perlu diperhatikan dalam masalah belajar. ${ }^{8}$

1. Kegairahan dan kesediaan untuk belajar

Seorang guru yang berpengalaman, tidak berusaha mendorong muridnya untuk mempelajari sesuatu diluar kemampuannya. Dan ia tidak akan memompakan ke otaknya pengetahuan yang tidak sesuai dengan kematangannya atau tidak sejalan dengan pengalamannya yang lalu. Ia juga tidak akan menggunakan metode yang tidak sesuai dengan mereka. Disamping itu ia tidak akan mengabaikan keadaan 
kejiwaan mereka. Kesimpulannya dapat dikatakan bahwa dalam proses pembelajaran, guru harus memperhatikan keadaan peserta didik, tingkat pertumbuhan dan pembedaan perorangan yang terdapat di anatara mereka.

2. Membangkitkan minat peserta didik

Guru harus menjaga aturan kelas, dan menjadikan peserta didik bergairah menerima pelajaran. Dia juga harus mengarahkan kelakuan mereka kepada yang baik yang diinginkan, dengan suka rela dan atas kemauan sendiri bekerja dan bergerak. Jalan untuk itu adalah membangkitkan minat peserta didik dengan berusaha memenuhi keperluan mereka, dan menjaga bakat mereka, serta mengarahkannya kepada yang benar.

3. Menumbuhkan sikap dan bakat yang baik

Banyak macam kegiatan yang dilakukan peserta didik dalam belajar, membangkitkan minat dan keperluannya, pembentukan berbagai bakat dan sikap, yang menjadi bagian dari kepribadian mereka.

4. Mengatur proses pembelajaran dan mengatur pengalaman belajar serta kegiatan-kegiatan yang berhubungan dengannya, adalah faktor utama dalam berhasilnya proses pembelajaran, karena ia memudahkan peserta didik untuk memperoleh pengalamn tersebut dan dalam pemanfaatnnya. Pengaturan itu terjadi dengan menghubungkan unsur-unsur pelajaran dengan peserta didik, dan menjadikannya kesatuan yang terpadu, yang berkisar pada masalahmasalah yang menjadi perhatian mereka, dengan demkian pembelajaran menjadi bermakna.

5. Berpindahnya pengaruh belajar dan pelaksanaannya kedalam kehidupan nyata.

6. Agar proses pembelajaran berhasil dan berguna dalam kehidupan di luar sekolah, guru harus mengerti dasar-dasar yang memungkinkan terjadinya perpindahan pengaruh belajar ke dalam kehidupan diluar sekolah.

7. Hubungan manusiawi dalam proses belajar

Proses belajar dapat berjalan dengan lancar atau tersendat-sendat, tergantung kepada hubungan sosial dalam kelas antara guru dan peserta didik dan diantara peserta didik sesama mereka. Yakni sesuai dengan keadaan sosial yang menonjol dalam kelas. Oleh karena itu guru juga baru memahami berbagai hubungan sosial dalam proses pembelajaran.

Disisi lain kompetensi kepribadian ditinjau dalam konteks budaya mampu membentuk karakter peserta didik, saat ini di dunia pendidikan lagi gencar-gencarnya meneriakkan pendidikan budaya dan karakter bangsa. Ternyata bangsa ini baru sadar bahwa moral bangsa sudah ada 
penurunan. Hal ini memang terbukti dengan semakin turunya moral rakyat. Bukan hanya rakyat biasa, gurupun banyak yang melakukan hal yang sama. Pendidikan karakter merupakan upaya-upaya yang dirancang dan dilaksanakan secara sistematis untuk membantu peserta didik memahami nuilai-nilai perilaku manusia yang berhubungan dengan Tuhan yang Maha Esa, diri sendiri, sikap, perasaan, perkataan, dan perbuatan berdasarkan norma-norma agama, hukum, tata krama, budaya, dan adat istiadat.

Lebih lanjut dijelaskan bahwa pendidikan karakter adalah segala sesuatu yang dilakukan guru, yang mampu mempengaruhi karakter peserta didik. Guru membantu membantuk watak peserta didik. Hal ini mencakup keteladanan bagaimana perilaku guru, cara guru berbicara atau menyampaikan materi, bagaimanapun guru bertoleransi, dan berbagai hal terkait lainnya.

Dari uraian di atas, dapat disimpulkan bahwa kompetensi kepribadian ditinjau dalam konteks budaya, dapat menciptakan proses pemebelajaran atraktif. Sehingga dengan pembelajaran aktraktif ini peserta didik menjadi aktif dan tidak membosankan. Disisi lain dapat membentuk karakter peserta didik cerdas secara intelektual dan berakhlak mulia.

\section{Konteks Ekonomi}

Kompetensi kepribadian ditinjau dalam konteks ekonomi dapat meningkat kreatifitas guru, seperti mengadakan variasi dalam strategi metode pembelajaran, selalu mengupdate informasi kepada peserta didik. Derasnya arus informasi yang berkembang di masyarakat menuntut setiap orang untuk bekerja keras agar dapat mengikuti dan memahaminya, kalau tidak guru akan ketinggalan informasi. Demikian halnya dalam pembelajaran di sekolah, untuk memperoleh hasil yang optimal guru dituntut tidak hanya mengandalkan terhadap apa yang ada di kelas, tetapi harus mampu dan mau menelusuri berbagai sumber pembelajaran yang diperlukan.

Guru dituntut tidak hanya mendayagunakan sumber-sumber pembelajaran yang ada di sekolah (apalagi hanya membaca buku ajar) tetapi dituntut untuk mempelajari berbagai sumber, seperti majalah, surat kabar, internet dan web. Hal ini penting, agar apa yang dipelajari sesuai dengan kondisi dan perkembangan masyarakat, sehingga tidak terjadi kesenjangan dalam pola pikir peserta didik.

Dari berbagai sumber yang ada mungkin didayagunakan dalam pembelajaran, sedikitnya dapat dikelompokkan sebagai berikut:

1. Manusia (people), yaitu orang yang menyampaikan pesan pembelajaran secara langsung; seperti guru, konselor, administrator, yang diniati secara khusus dan disengaja untuk kepentingan pembelajaran (by design). Disamping itu, ada yang tidak diniati untuk kepentingan pembelajaran tetapi memilki keahlian yang bisa 
dimanfaatkan untuk kepentingan pembelajaran, misalnya penyuluh kesehatan, polisi, pemimpin perusahaan, dan pengurus koperasi. Orang tersebut tidak diniati, tetapi sewaktu-waktu bisa dimanfaatkan untuk kepentingan pembelajaran.

2. Bahan (material), yaitu sesuatu yang mengandung pesan pembelajaran; baik yang diniati secara khusus seperti film pendidikan, peta, grafik, buku paket, dan sebagainya, yang biasanya disebut media pembelajaran (instructional media), maupun bahan yang bersifat umum; seperti film dokumentasi Pemilu Presiden bisa dimanfaatkan untuk kepentingan pembelajaran.

3. Lingkungan (setting), yaitu ruang dan tempat ketika sumber-sumber dapat berinteraksi dengan para peserta didik. Ruang dan tempat yang diniati secara sengaja untuk kepentingan pembelajaran, misalnya ruang perpustakaan, ruang kelas, laboratorium, dan ruang mikro teaching. Di samping ada juga ruang yang tidak diniati untuk kepentingan pembelajaran, namun bisa dimanfaatkan; mislanya museum, kebun binatang, kebun raya, candi, dan tempat-tempat beribadat.

4. Alat dan peralatan (tool and equipment), yaitu sumber pembelajaran untuk produksi dan memainkan sumber-sumber lain. Alat dan peralatan untuk produksi misalnya kamera untuk prodiksi foto, tape recorder untuk rekaman. Sedangkan alat dan peralatan yang digunakan untuk memainkan sumber lain, misalnya proyektor film, televisi, dan radio.

5. Aktivitas (activities), yaitu sumber pembelajaran yang merupakan kombinasi antara suatu teknik dengan sumber lain untuk memudahkan (facilitates) belajar, misalnya karyawisata.

Tidak diragukan lagi, bahwa usaha perbaikan dan penilaian mendalam terhadap diri sendiri, perlu selalu diadakan oleh setiap guru. Alat yang digunakan untuk itu banyak dan bermacam-macam antara lain membaca buku-buku yang diperlukan, baik mengenai pengetahuan agama, Pancasila dan UUD 45, ilmu jiwa dan mengakses internet sebagainya. Juga dapat dilakukan melaui kursus, sekolah, diskusi atau mendengarkan berbagai kuliah dan ceramah tentang berbagai hal yang diperlukan.

Dari uraian diatas, dapat disimpulkan bahwa menggunakan fasilitas pembelajaran harus senantiasa dilakukan oleh guru. Era globalisasi sekarang ini teknologi informasi dan komunikasi bukan lagi monopoli Barat. Siapa saja bisa menggunakannya. Oleh sebab itu guru dituntut untuk melakukan pembaruan dalam sistem pembelajaran. Guru harus mampu mengoperasikan komputer dan mengintegrasikannya ke dalam proses pembelajaran. Mau tidak mau guru harus melakukannya karena kalau tidak 
dilakukan maka guru tersebut akan ketinggalan informasi dan dicap sebagai guru yang ketinggalan zaman.

\section{Konteks Hukum}

Kompetensi kepribadian ditinjau dalam konteks hukum, mampu mengontrol dan mengendallikan guru yang menyimpang yang diatur dalam kode etik guru. Peranan guru semakin penting dalam era global. Hanya melalui bimbingan guru yang profesional, setiap siswa dapat menjadi sumber daya manusia yang berkualitas, kompetitif dan produktif sebagai aset nasional dalam menghadapi persaingan yang makin ketat dan berat sekarang dan dimasa datang. Dalam melaksanakan tugas profesinya guru Indonesia menyadari sepenuhnya bahwa perlu ditetapkan Kode Etik Guru Indonesia sebagai pedoman bersikap dan berperilaku yang mengejewantah dalam bentuk nilai-nilai moral dan etika dalam jabatan guru sebagai pendidik putera-puteri bangsa. ${ }^{9}$

1. Guru berbakti membimbing anak didik seutuhnya untuk membentuk manusia pembangun yang berjiwa Pancasila

2. Guru memiliki kejujuran Profesional dalam menerapkan Kurikulum sesuai dengan kebutuhan anak didik masing-masing .

3. Guru mengadakan komunikasi terutama dalam memperoleh informasi tentang anak didik, tetapi menghindarkan diri dari segala bentuk penyalahgunaan.

4. Guru menciptakan suasana kehidupan sekolah dan memelihara hubungan dengan orang tua murid sebaik-baiknya bagi kepentingan anak didik

5. Guru memelihara hubungan dengan masyarakat disekitar sekolahnya maupun masyarakat yang luas untuk kepentingan pendidikan .

6. Guru secara sendiri-sendiri dan atau bersama-sama berusaha mengembangkan dan meningkatkan mutu Profesinya .

7. Guru menciptakan dan memelihara hubungan antara sesama guru baik berdasarkan lingkungan maupun didalam hubungan keseluruhan .

8. Guru bersama-sama memelihara membina dan meningkatkan mutu Organisasi Guru Profesional sebagai sarana pengapdiannya.

9. Guru melaksanakan segala ketentuan yang merupakan kebijaksanaan Pemerintah dalam bidang Pendidikan.

Dari uraian di atas dapat disimpulkan bahwa, dengan adanya kode etik guru diharapkan agar para guru senantiasa mentaati kode etik tersebut. Apabila ada guru yang menlangggar kode etik tersebut dia akan dikenakan sangsi moral dari masyarakat. Kepribadian guru yang tercermin dalam

${ }^{9}$ Veri Kaka, Yaka Online, http://verykaka.wordpress.com, diakses pada tanggal 29 Maret 2018 pukul 20.30 WIB. 
segala penampilannya itu hendaknya menarik, menyenangkan stabil, agar peserta didik mendapat teladan yang baik dalam pertumbuhan pribadinya, serta tidak ragu-ragu bertindak dan bertingkah laku.

\section{Konteks Agama}

UU NO. 14 Tahun 2005 Tentang Guru dan Dosen terkait dengan kompetensi kepribadian ditinjau dalam konteks agama. Agama mendungkung bahkan turut menguatkan tentang kompetensi kepribadian yang harus dimiliki oleh guru. Karena pada dasarnya subtansi dari ajaran Pendidikan Islam itu sendiri membentuk akhlak mulia.

Nabi Muhammad shalallahu 'alaihi wa salam, rasul yang mulia mendapat pujian Allah. Karena ketinggian akhlak beliau sebagaimana firmanNya dalam surat Al Qalam ayat 4.

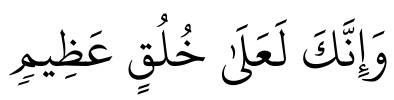

\section{Artinya:}

Dan Sesungguhnya kamu benar-benar berbudi pekerti yang agung.

Demikian juga apa yang dikatakan oleh Ummul Mu'minin 'Aisyah rodhiyallahu 'anha,

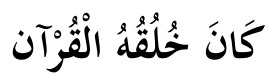

Bahwa Akhlak Nabi shollallahu 'alaihi was sallam adalah Al Qur'an

Bahkan beliau shalallahu 'alaihi wa sallam sendiri menegaskan bahwa kedatangannya adalah untuk menyempurnakan akhlak yang ada pada diri manusia.

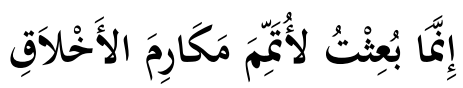

"Sesungguhnya aku (Nabi Sholallahu 'alaihi was sallam) diutus untuk menyempurnakan akhlak yang mulia" (HR.Ahmad, lihat Ash Shahihah oleh Asy Syaikh al Bani no.45 dan beliau menshahihkannya).

Anas bin Malik radhiallahu 'anhu seorang sahabat yang mulia menyatakan : "Rasulullah shalallahu 'alaihi wa sallam adalah manusia yang paling baik budi pekertinya."(HR.Bukhari dan Muslim). Dalam hadits lain anas memuji beliau shalallahu 'alahi wasallam : "Belum pernah saya menyentuh sutra yang tebal atau tipis lebih halus dari tangan rasulullah shalallahu 'alaihi wasallam. Saya juga belum pernah mencium bau yang lebih wangi dari bau rasulullah shalallahu 'alaihi wasallam. Selama sepuluh tahun saya melayani rasulullah shalallahu 'alahi wa sallam, belum pernah saya dibentak atau ditegur perbuatan saya : mengapa engkau berbuat ini ? atau mengapa engkau tidak mengerjakan itu ?" (HR. Bukhari dan Muslim). ${ }^{10}$

${ }^{10}$ Aditiya Budiman, Tazkiyatun Nufus, http://alhijroh.com, di akses pada tanggal 29 Maret 2018. Pukul 21.45 WIB. 
Akhlak merupakan tolak ukur kesempurnaan iman seorang hamba sebagaimana telah disabdakan oleh rasulullah shalallahu 'alaihi wasallam : "Orang mukmin yang paling sempurna imannya ialah yang terbaik akhlaknya." (HR Tirmidzi, dari abu Hurairah radhiallahu 'anhu, diriwayatkan juga oleh Ahmad. Disahihkan Al Bani dalam Ash Shahihah No.284 dan 751). Dalam riwayat Bukhari dan Muslim dari Abdillah bin amr bin Al 'Ash radhiallahu 'anhuma disebutkan : "Sesungguhnya sebaik-baik kalian ialah yang terbaik akhlaknya. ${ }^{11}$

Selain itu, Pekerjaan guru adalah pekerjaan yang mulia karena berarti ia memberikan sesuatu yang kekal abadi yang sewaktu-waktu dapat dipergunakan dan bermanfaat bagi pemiliknya. Allah akan mengangkat derajat orang-orang yang berilmu (guru). Sebagaimana Frman Allah SWT:

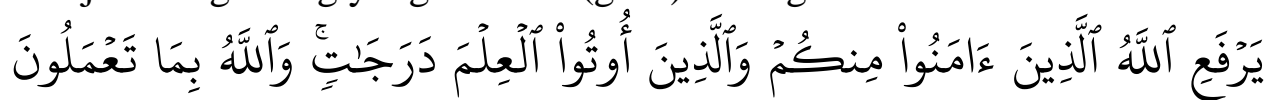

\section{Artinya:}

Allah akan meninggikan orang-orang yang beriman di antaramu dan orang-orang yang diberi ilmu pengetahuan beberapa derajat. dan Allah Maha mengetahui apa yang kamu kerjakan. (Al-Mujadalah: 11)

Ayat di atas tidak menyebut secara tegas bahwa Allah akan meninggikan derajat orang berilmu. Tetapi, menegaskan bahwa mereka memiliki derajat-derajat, yakni yang lebih tinggi dari pada sekadar beriman. Tidak disebutkannya kata meninggikan itu sebagai isyarat bahwa sebenarnya ilmu yang dimilikinya itulah yang berperanan besar dalam ketinggian derajat yang diperolehnya, bukan akibat dari faktor di luar ilmu itu. ${ }^{12}$ Ini mengindikasikan bahwa pekerjaan guru merupakan pekerjaan yang mulia di sisi Allah swt.

Mengajar adalah perkara besar dan penting meski ia tidak sebagaimana harta yang nyata-nyata bisa dilihat mata dan dirasakan indra mnusia. Oleh karenanya manusia dihargai dengan banyaknya pengetahuan yang ia miliki. Dalam struktur organisasi perusahaan pun demikian. Atasan adalah orang yang dianggap memiliki pengetahuan yang paling baik, baik pengetahuan itu diperoleh dari belajar maupun dari praktik pengalaman. Karena itulah di negeri ini para sarjana mendapat posisi jabatan yang lebih baik daripada SMA yang telah berpengalaman bertahun-tahun. Hal itu semata-mata karena pengetahuan mereka dianggap lebih baik dan mereka memiliki dasar pengetahuan yang kuat.

Disatu sisi orang tidak mempunyai akhlak akan menimbulkan dekandensi moral yang sekarang menjadi sorotan terhadap pendidikan kita. Mengapa hal ini bisa terjadi? Salah satu akibat terbesar pada hidup dan

\footnotetext{
${ }^{11}$ Ibid.,,,

${ }^{12}$ Quraish Shihab, Tafsir al-Misbah, Vol. 13, (Jakarta: Lentera Hati, 2002), hal. 491
} 
kehidupan manusia serta masyarakat, yaitu tidak peduli pada agama (Tuhan) adalah adanya suatu sikon yang oleh para praktisi pendidikan, sosiolog, dan kaum agamawan disebut sebagai dekadensi moral. Dekadensi berasal dari kata dekaden (keadaan merosot dan mundur) dan moral atau akhlak. Dengan demikian, dekadensi moral merupakan atau bermakna sikon moral yang merosot (jatuh) atau sementara mengalami (dalam keadaan) mundur atapun kemunduran; kemunduran dan kemorosatan yang terus menerus (sengaja atapun tidak sengaja) terjadi serta sulit untuk diangkat atau diarahkan menjadi seperti keadaan semula atau sebelumnnya.

Di samping ketidakpedulian pada agama, sikon sosial-kultural masyarakat yang buruk; motivasi agar memperoleh kepuasan melalui banyak (adanya) harta benda; serta berbagai faktor dan kejahatan lainnya, mempunyai andil besar pada dekadensi moral masyarakat di banyak tempat dan pada berbagai bangsa. Karena paduan sikon yang buruk dan upaya mencapai semua keinginan hati, biasa membangun motivasi untuk memenuhinya dengan berbagai cara. Jika upaya pemenuhan itu tidak tercapai dengan hal-hal wajar, normal, baik dan benar, maka akan beralih melalui pelanggaran hukum, norma, etika, dan seterusnya. Dan ketika seseorang memasuki peralihan tersebut, maka ia telah terjerumus ke dalam dekadensi moral.

Dekadensi moral bukan lingkaran kekuatan ataupun lingkungan yang membentuk manusia agar bertindak negatif serta menabrak nilai-nilai standar kebaikan hidup dan kehidupan. Tetapi, sifat dan sikap negatif manusia lah yang menciptakan atau memperlihatkan dekadensi moral.

Pada sikon tersebut, manusia telah menciptakan ketidakteraturan dengan cara mematahkan rambu-rambu moral dan teguran suci suara hatinya, sehingga berdampak pada kerusakan sistem sosial-kultural dan hukum serta norma-norma, dan lain sebagainya yang berlaku dalam komunitas masyarakat. Akibatnya, hampir semua sistem dalam komunitas tersebut menjadi rusak dan mengalami degradasi serta dekadensi.

Kesimpulannya dari uraian di atas, Akhlak atau dalam bahasa inggrisnya attitude merupakan hal yang sangat penting disematkan dan dijadikan jatidiri oleh setiap individu. Akhlak adalah persaudaraan di dalam Allah dengan kesediaan menolong saudara di dalam hal-hal yang disenanginya, memenuhi hak-haknya di saat kehadirannya, menasehatinya jika engkau melihatnya terpeleset, mendorongnya jika melihatnya baik, dan tidak pelit terhadapnya. Selanjutnya definisi lain akhlak adalah sikap yang punya tujuan baik, i'tikad baik, dan hati yang bersih. Jadi, akhlak seseorang bisa dilihat dari cara dia memperlakukan orang lain, keluarganya, temannya, saingannya, tamunya, anak buahnya, atau pendahulunya.

Dengan adanya akhlak yang baik maka seseorang akan memberikan stimulasi yang baik pada dirinya maupun orang lain, sehingga akan tercipta 
"kenyamanan" kedua belah pihak. Di Amerika, rata-rata syarat yang paling utama seseorang bisa diterima kerja di "perusahaan tertentu" adalah sikap/ akhlak yang baik. Namun, sebaliknya di Indonesia yang lebih mengutamakan parameter kemampuan kognitif/ akademik seseorang. Contohnya sistem pendidikan yang diterapkan di Indonesia, yaitu syarat kelulusan berupa standar nilai (kemampuan kognitif / hardskill), sehingga peserta didik yang bisa mencapai standar nilai lah yang akan dinyatakan lulus walaupun sebenarnya si peserta didik menyontek pada saat ujian atau suka tawuran. ${ }^{13}$

Sebaliknya orang tidak mempunyai kepribadian yang baik dan jauh dari agama akan mengakibatkan dekandensi moral (kemerosotan moral) bahkan mengalami degradasi moral, dia akan melakuakan berbagai cara dan berbuat tindak kejahatan dimana-mana demi mewujudkan cita-citanya.

\section{KESIMPULAN}

Analisis dalam Konteks Sosial. Kompetensi kepribadian ditinjau dalam konteks sosial mempunyai nilai filosofis upaya untuk memberdayakan pendidikan masyarakat, disisi lain kebijakan tentang undang-undang guru dan dosen terkait kompetensi kepribadian guru sebagai agen pembelajaran hanya terfokus pada pendidikan formal saja kurang memperhatikan pendidikan non formal dan informal, karena keberhasilan pendidikan yang dilakukan oleh guru tidak hanya di ukur dari ranah kognitif (kecerdasan) saja tapi harus memperhatikan ranah afektif dan psikomotorik. Selanjutnya sikap toleransi harus tertanam pada ssosok guru yang bermoral sehingga dalam proses pembelajaran tidak membeda-membedakan satu dengan yang lainnya berdasarkan ras, suku, agama, dan lain-lain.

Analisis dalam Konteks Budaya. Kompetensi kepribadian ditinjau dalam konteks budaya, dapat menciptakan proses pembelajaran atraktif. Sehingga dengan pembelajaran aktraktif ini peserta didik menjadi aktif dan tidak membosankan. Disisi lain dapat membentuk karakter peserta didik cerdas secara intlektual dan berakhlak mulia.

Analisis dalam konteks Ekonomi. Menggunakan fasilitas pembelajaran harus senantiasa dilakukan oleh guru. Era globalisasi sekarang ini teknologi informasi dan komunikasi bukan lagi monopoli Barat. Siapa saja bisa menggunakannya. Oleh sebab itu guru dituntut untuk melakukan pembaruan dalam sistem pembelajaran. Guru harus mampu mengoperasikan komputer dan mengintegrasikannya ke dalam proses pembelajaran. Mau tidak mau guru harus melakukannya karena kalau tidak dilakukan, maka guru tersebut akan ketinggalan informasi dan dicap sebagai guru yang ketinggalan zaman. Analisis dalam konteks Hukum. Kode etik diharapkan agar para guru senantiasa mentaati kode etik tersebut. Apabila ada guru yang melanggar kode etik tersebut dia akan dikenakan

\footnotetext{
${ }^{13}$ Ali Ahkamulloh, Tabuhun Online, http://tanbihun.com/, di akses pada tanggal 29 Maret 2018, pukul 20.12 WIB
} 
sangsi moral dari masyarakat. Kepribadian guru yang tercermin dalam segala penampilannya itu hendaknya menarik, menyenangkan stabil, agar peserta didik mendapat teladan yang baik dalam pertumbuhan pribadinya, serta tidak ragu-ragu bertindak dan bertingkah laku.

Analisis dalam konteks Agama. Memiliki akhlak yang baik maka seseorang akan memberikan stimulasi yang baik pada dirinya maupun orang lain, sehingga akan tercipta "kenyamanan" kedua belah pihak. Di Amerika, rata-rata syarat yang paling utama seseorang bisa diterima kerja di "perusahaan tertentu" adalah sikap/ akhlak yang baik. Namun, sebaliknya di Indonesia yang lebih mengutamakan parameter kemampuan kognitif/ akademik seseorang. Contohnya sistem pendidikan yang diterapkan di Indonesia, yaitu syarat kelulusan berupa standar nilai (kemampuan kognitif / hardskill), sehingga pesrta didik yang bisa mencapai standar nilai lah yang akan dinyatakan lulus walaupun sebenarnya si pesrta didik menyontek pada saat ujian atau suka tawuran. Sebaliknya orang tidak mempunyai kepribadian yang baik dan jauh dari agama akan mengakibatkan dekandensi moral (kemerosotan moral) bahkan mengalami degradasi moral, dia akan melakuakan berbagai cara dan berbuat tindak kejahatan dimana-mana demi mewujudkan citacitanya.

\section{DAFTAR PUSTAKA}

Ace Suryadi, Tilaar, 1994. Analisis Kebijkan Pendidikan suatu Pengantar, Bandung: PT Remaja Rosdakarya,

Aditiya Budiman, Tazkiyatun Nufus, http://alhijroh.com, di akses pada tanggal 29 Maret 2018. Pukul 21.45 WIB.

Ali Ahkamulloh, Tabuhun Online, http://tanbihun.com/, di akses pada tanggal 29 Maret 2018, pukul 20.12 WIB

Bagus Hedananto, 2006. Menjadi Guru Bermoral Profesional, Yogyakarta: Kerasi Wacana

Mulyasa. E, 2008. Menjadi Guru Profesional, Bandung: PT Remaja Rosdakarya. 2008. Standar Kompetensi dan Sertifikasi Guru, Bandung: PT Remaja Rosdakarya.

Emil Durkhaim, 1961. Pendidikan Moral, Jakarta: Erlangga.

Herdana Nawawi, Mimi Martini, 2004. Kebijakan Pendidikan di IndonesiaTinjauan Dari sudut Hukum, Yogyakarta: Gajah Mada Universitas.

Ilyas Yuhar, 2007. Kuliah Akhlak, Yogyakarta: Lembaga pengkajian dan Pengalaman Islam (LPPI).

Muhammad Ali al-Hasyimi, 2004. Muslim Ideal, Jakarta: Mitra Pustaka.

Moh. Uzer Usman, 2009. Menjadi Guru Profesional, Bandung: PT Remaja Rosdakarya.

Quraish Shihab, 2002. Tafsir al-Misbah, Pesan, Kesan, Keserasian al-Qur'an Voumel. 13, Jakarta: Lentera Hati. 
Syaiful Bahri Djaramah, 2008. Psikologi Belajar, Jakarta: PT Rineka Cipta.

Syarnubi, S. (2017). Manajemen Konflik Dalam Pendidikan Islam dan Problematikanya: Studi Kasus di Fakultas Dakwah UIN-SUKA Yogyakarta. Tadrib: Jurnal Pendidikan Agama Islam, 2(1), 151-178.

Undang-Undang Guru dan Dosen, 2009. Yogyakarta: Pustaka Pelajar.

Veri Kaka, Kaka Online, http://verykaka.wordpress.com, diakses pada tanggal 29 Maret 2018 pukul 20.30 WIB.

Daradjat Zakiah, 2005. Kepribadian Guru, Jakarta: PT Bulan Bintang. 